\title{
Odour Nuisance near Semi-Aerobic Landfill: A Distance-Based Study in Malaysia
}

\author{
Tengku Nuraiti Tengku Izhar, Nor Azam Ramli, and Ahmad Shukri Yahaya
}

\begin{abstract}
The decomposition of biodegradable waste in landfills is known to produce odour emissions that cause discomfort to nearby residents. Therefore, the aim of this study is to investigate perception of odour as a nuisance among residents in relation to their distance from a landfill. A survey is conducted, and 507 respondents living within a 7.0 kilometre radius from the landfill participated. Questionnaires are sent out to the respondents to investigate their background, socioeconomic status, and perception on odour. The selected landfill is semi-aerobic and is used for the disposal of non-hazardous domestic and industrial wastes. Respondents for radius $<0.9 \mathrm{~km}$ are employees of the landfill. Based on survey results, almost $26 \%$ of the respondents strongly agree that 'odour is a nuisance'. The level of agreement on 'odour is a nuisance' decreases with distance; that is, even respondents (1\%) who live within $6.0-6.9 \mathrm{~km}$ agree to this perception. A possible reason is that odour concentration is not only high at the origin/source, but also emanates from waste collection and transportation. Respondent perception on 'odour is a nuisance' is investigated in terms of race, age, type of house, education, occupation, and income.
\end{abstract}

Index Terms-Odour, odorous emission, odour nuisance, semi-aerobic landfill

\section{INTRODUCTION}

Landfills have been the most common sources of odour emissions and complaints [1]. Odour from landfill sites principally originate from atmospheric release of compounds formed during the biological and chemical processes of waste decomposition [2]. In Malaysia, the major problem on landfill sites deals with odour from waste decomposition. Approximately 110 landfill sites are under operation [3]. Landfills in the country are of two types: open dumping and controlled dumping sites. Incidentally, Proper sanitary landfill concepts have not been fully implemented due to financial and technology constraints [4]. Clearly, landfill emissions can be a source of major nuisance to nearby residents. Landfill gas emissions contain microbes, particles, and odorous substances. The main chemical compounds in landfill gas include saturated and unsaturated hydrocarbons, acidic hydrocarbons, organic alcohols, aromatic hydrocarbons, halogenated compounds, sulphur compounds,

Manuscript received December 10, 2012; revised January 21, 2013. This work was supported in part by the Ministry of Higher Education Malaysia under Fundamental Research Grant Scheme.

Tengku Nuraiti Tengku Izhar is with the Universiti Malaysia Perlis, 02600 Kangar, Perlis, Malaysia (e-mail: nuraiti@ unimap.edu.my).

Nor Azam Ramli is with Universiti Sains Malaysia, 14300 Pulau Pinang, Malaysia. (e-mail: ceazam@eng.usm.my).

Ahmad Shukri Yahaya is with the Universiti Sains Malaysia, 14300 Pulau Pinang, Malaysia (e-mail: shukri@eng.usm.my). and inorganic compounds [5]. Inasmuch as the concentrations of these compounds are usually very low, the corresponding olfactory thresholds are even lower. In fact, the human nose is the most sensitive detector of these compounds, noting that gas concentrations are far below the detection limit of measuring equipment. The potential damaging health effects of airborne microbes and particles is widespread. However, there is only limited research on the effects of odour [6]. One possible reason is that issues related to odour complaints from landfill-affected communities are difficult to deal with [7].

Individual responses to odour vary and are subjective. Sensitivity, coping style, cognition, and earlier experience with odour can alter an individual's response to odour. Meanwhile, socioeconomic status can also affect perceptions on odour (i.e., as a nuisance). Individual sensory responses to odour considerably vary from compound to compound, if not from person to person [8]. Perception on smell is also affected by the load of odour 'trapped' in a place, air dispersion, topography, weather, and distance from the odour source. Municipal landfill sites are one of the main sources of odorous nuisance in the environment and can incite complaints from urban communities located within the vicinity of the landfill. Expectedly, odour is one major reason for public opposition to landfill sites [9]. Therefore, accurate prediction and control of odorous emissions and proper treatment of municipal wastes are necessary in order to reduce the effect of odour on the environment [10].

\section{MATERIALS AND METHODS}

\section{A. Pulau Burung Landfill Site}

In this research, the odour source is a semi-aerobic landfill. The landfill handles disposal of non-hazardous domestic and industrial wastes. Landfill emissions are monitored to explore potential odour emission and odour from the landfill gas. The target site is Pulau Burung Landfill Site (PBLS). PBLS is located in Nibong Tebal, Pulau Pinang, Malaysia. Fig. 1 shows the location of Nibong Tebal, south of Seberang Perai, Pulau Pinang.

The coordinates of PBLS is N05 $11^{\prime}$ 9.986", E100 25' 6.093 '. Its altitude is 5.61 above sea level and is located near the sea. PBLS is a semi-aerobic landfill with an operational area of 33 hectares. This landfill serves as a disposal area for domestic non-hazardous and individual wastes. Waste from both Penang Island and Seberang Perai are sent to this landfill. There is no landfill gas collection at PBLS. PBLS constructed leachate treatment facilities and a liner system to 
avoid leachate from infiltrating the ground. Daily cover is used to avoid infiltration of storm water into the waste layer, and to minimize odour release from the dumping site to the environment. The composition of waste sent to PBLS is shown in Table I.

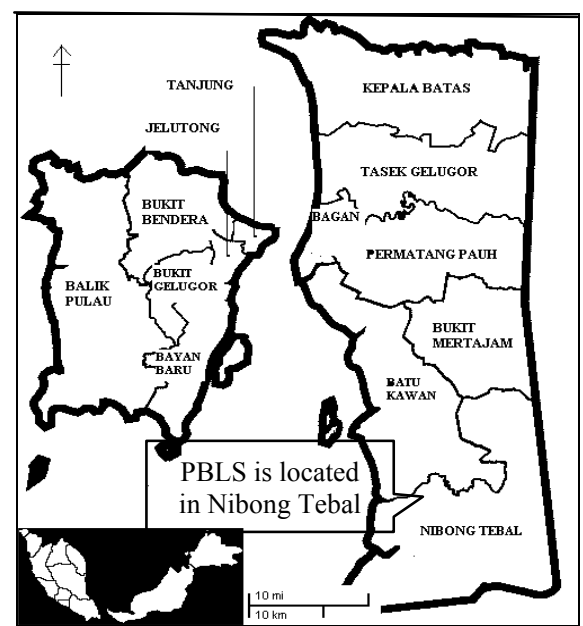

Fig. 1. Nibong Tebal located in the southern part of Pulau Pinang [11]

TABLE I: WASte Composition AT the PUlau BURUnG LANDFILL Site

\begin{tabular}{cc}
\hline TYPE & $\%$ \\
\hline Food & 35.72 \\
Plastic & 22.19 \\
Yard waste & 13.27 \\
Cardboard & 6.02 \\
Paper & 10.59 \\
Textile & 5.10 \\
Glass & 3.20 \\
Rubber & 0.89 \\
Wood & 0.58 \\
Non-ferrous metal & 2.10 \\
Ferrous metal & 0.34 \\
\hline
\end{tabular}

High percentage of organic waste supplies the necessary microorganisms essential for material decomposition. Landfill gas and odorous emission from the semi-aerobic landfill are investigated by monitoring the gaseous emissions for 28 days. Methane $\left(\mathrm{CH}_{4}\right)$ and carbon dioxide $\left(\mathrm{CO}_{2}\right)$ are the major gases emitted from the landfill. Other hazardous and odorous gases include carbon monoxide $(\mathrm{CO})$ and hydrogen sulphide $\left(\mathrm{H}_{2} \mathrm{~S}\right)$. Gas is monitored at the waste layer is it has been used for six years. Based on the age of waste layer, the phase of the landfill is possibly on its methanogenesis.

Table II shows the gaseous emissions of PBLS, which is high and odorous, and even pose as nuisance to nearby communities. The highest $\mathrm{CH}_{4}$ emission is $68.30 \%$ and its overall mean is $49.92 \%$. The highest standard deviation is obtained during the 9 a.m. monitoring. Overall, these indicate the existence of high $\mathrm{CH}_{4}$ emission. The mean of $\mathrm{CO}_{2}$ is $39.30 \%$. Its highest standard deviation value is 19.69 . High $\mathrm{CO}_{2}$ emissions have been observed at 9 a.m. (i.e., every morning), with an overall mean of $1.52 \mathrm{ppm}$. $\mathrm{CO}$ is a minor gas emitted from the landfill. High $\mathrm{H}_{2} \mathrm{~S}$ emission has also been observed at 9 a.m., with an overall mean of $225.03 \mathrm{ppm}$. The monitoring pipes are located at the waste layer. Considering that they are in their methanogenesis phase, ample sulphate compound reduces waste to $\mathrm{H}_{2} \mathrm{~S}$ by sulphate-reducing microorganisms. It is highly likely that the highest $\mathrm{H}_{2} \mathrm{~S}$ emission occurs during this time of biodegradation [12].

TABLE II: Gaseous EMISSION From the PULAU BurUng LANDFiLl Site

\begin{tabular}{|c|c|c|c|c|c|c|}
\hline \multirow[b]{2}{*}{ Emission } & \multirow{2}{*}{$\begin{array}{c}\text { Statistic } \\
\text { Descriptive }\end{array}$} & \multicolumn{5}{|c|}{ Time } \\
\hline & & 9 a.m. & $\begin{array}{c}11 \\
\text { a.m. }\end{array}$ & 1 p.m. & 3 p.m. & 5 p.m. \\
\hline \multirow[t]{4}{*}{$\mathrm{CH}_{4}(\%)$} & Minimum & 0.20 & 0.10 & 0.30 & 0.10 & 34.20 \\
\hline & Maximum & 59.70 & 68.30 & 59.40 & 60.90 & 60.10 \\
\hline & Mean & 42.88 & 50.73 & 52.60 & 46.05 & 57.34 \\
\hline & $\begin{array}{l}\text { Std. } \\
\text { Deviation }\end{array}$ & 24.69 & 19.03 & 16.54 & 23.46 & 4.65 \\
\hline \multirow[t]{4}{*}{$\mathrm{CO}_{2}(\%)$} & Minimum & 0.10 & 0.10 & 0.10 & 0.10 & 27.00 \\
\hline & Maximum & 46.50 & 46.50 & 46.50 & 53.10 & 46.70 \\
\hline & Mean & 33.62 & 39.59 & 41.15 & 36.92 & 45.25 \\
\hline & $\begin{array}{l}\text { Std. } \\
\text { Deviation }\end{array}$ & 19.68 & 15.05 & 13.32 & 19.09 & 3.63 \\
\hline \multirow[t]{4}{*}{$\begin{array}{c}\mathrm{H}_{2} \mathrm{~S} \\
(\mathrm{ppm})\end{array}$} & Minimum & 9 & 15 & 10 & 4 & 115.00 \\
\hline & Maximum & 356 & 362 & 357 & 363 & 362.00 \\
\hline & Mean & 187.5 & 215.25 & $\begin{array}{c}240.3 \\
2\end{array}$ & 201.82 & 248.57 \\
\hline & $\begin{array}{l}\text { Std. } \\
\text { Deviation }\end{array}$ & $\begin{array}{c}112.57 \\
9 \\
\end{array}$ & 96.079 & $\begin{array}{c}93.32 \\
8 \\
\end{array}$ & $\begin{array}{c}108.53 \\
1 \\
\end{array}$ & 58.04 \\
\hline \multirow[t]{4}{*}{$\mathrm{CO}(\mathrm{ppm})$} & Minimum & 0 & 1.00 & 1.00 & 1.00 & 1.00 \\
\hline & Maximum & 8.00 & 4.00 & 3.00 & 3.00 & 3.00 \\
\hline & Mean & 1.79 & 1.46 & 1.57 & 1.21 & 1.57 \\
\hline & $\begin{array}{l}\text { Std. } \\
\text { Deviation }\end{array}$ & 1.79 & 0.84 & 0.69 & 0.50 & 0.742 \\
\hline
\end{tabular}

\section{B. Wind Profile}

Wind profile determines the direction to which contaminated gas stream would move across local terrain. Wind speed and wind direction are measured in this research to investigate the dispersion of gases and to determine with finality the ground concentration of pollutants. Both are measured using laser detector equipment. Evidently, wind direction and speed are important facets in this research, as it employs both sampling and survey. Wind direction affects the movement of gases from landfill to the amenities, and in and out of the landfill site. The instrument used for odour detection is located at PBLS. It is set on a flat land with no massive structures (e.g., big trees or tall buildings) to reduce interference of wind movement. The instrument is set up for monitoring from 9 a.m. to 5 p.m. for a week. In the duration of the survey, both wind speed and wind direction represent the wind profile in PBLS and their movement to Nibong Tebal.

\section{Questionnaire}

The developed questionnaire incorporates diversity, gender, institutional, behaviour, and public participation. Data collection is conducted through a designed questionnaire that uses Likert scale-type responses. The scales are as follows: 1, 'Strongly disagree' (strongly unfavourable to the statement); 2, 'Disagree' (unfavourable to the statement); 3, 'Agree' ( $60 \%$ agree with the statement); 4, 'Strongly agree' ( $\sim 80 \%$ agree with the statement), and 5, 'Completely agree' ( $\sim 9 \%$ agree with the statement). Data obtained from the questionnaire consist of respondent perception on solid waste and odour. The questionnaire also raises questions related to demographic issues and background, as these could influence the attitude of respondents toward odour nuisance. 


\section{Odour Monitoring}

Odour is measured by a photo ionization detector (PID) metre. The PID is designed for walk-through surveys and long-term (hours/days/weeks) trend logging. Direct reading measurement is applied during gas monitoring. Nine points have been selected at each radius of the research area, including the landfill site (radius of $<0.9 \mathrm{~km}$ ). Using PID, total volatile organic compound (TVOC) and $\mathrm{H}_{2} \mathrm{~S}$ data collection is employed. The PID also provides readings on temperature $\left({ }^{\circ} \mathrm{C}\right)$ and humidity $(\mathrm{RH})$. Odour measured at selected points represents gases originating from the landfill. They are considered part of odour quantity in the atmosphere. They can also change the perception of respondents in terms of classifying odour as a nuisance. The recorded odour data are then compared with the questionnaire results from the respondents.

\section{RESULTS AND DISCUSSION}

A total of 507 respondents answered the questionnaires. Notably, only a few differences in respondent characteristics exist. The ratio of respondents differs from one radius-distance to the other. Religion and socioeconomic status also differ across radius-distance. The respondents from $<0.9 \mathrm{~km}$ are the employees of the landfill. All employees are of Malay race; the respondents are $20-24$ years old. Expectedly, they experience odour more frequently than the rest of the respondents. The perception of respondents on odour as a nuisance for the other radii-distance differs in light of the variations in race and socioeconomic status.

TABLE III: RESPONDENT PERCEPTION ON ODOUR AS NUISANCE IN THEIR RESPECTIVE RADIUS-DISTANCE

\begin{tabular}{|c|c|c|c|c|c|}
\hline \multirow{2}{*}{$\begin{array}{l}\text { Distance } \\
\text { from } \\
\text { Landfill }\end{array}$} & \multicolumn{5}{|c|}{ Agreement Level } \\
\hline & $\begin{array}{l}\text { Strongly } \\
\text { Disagree } \\
\end{array}$ & Disagree & Agree & $\begin{array}{c}\text { Strongly } \\
\text { Agree }\end{array}$ & $\begin{array}{c}\text { Completely } \\
\text { Agree } \\
\end{array}$ \\
\hline$<0.9 \mathrm{~km}$ & - & 1 & 15 & 7 & 4 \\
\hline $\begin{array}{l}1.0-1.9 \\
\text { km } \\
\end{array}$ & 8 & 10 & 9 & 2 & - \\
\hline $\begin{array}{l}3.0-3.9 \\
\text { km }\end{array}$ & 22 & 9 & 5 & - & - \\
\hline $\begin{array}{l}4.0-4.9 \\
\text { km }\end{array}$ & 44 & 7 & 7 & 2 & - \\
\hline $\begin{array}{l}\text { 5.0-5.9 } \\
\text { km }\end{array}$ & 38 & 29 & 7 & - & - \\
\hline $\begin{array}{l}\text { 6.0-6.9 } \\
\text { km }\end{array}$ & 148 & 89 & 18 & 3 & - \\
\hline$>7.0 \mathrm{~km}$ & 7 & 11 & 5 & - & - \\
\hline
\end{tabular}

Table III shows the number of respondents and their perception on odour as a nuisance. The survey finds that $55.56 \%$ of the respondents agree, $25.93 \%$ strongly agree, and $14.81 \%$ completely agree with the ill smell of the odour at $<0.9 \mathrm{~km}$. The total percentage is high, primarily because majority of the respondents work at the landfill. The percentage is also high at the distance nearer to the odour source. For those within the $1.0-1.9 \mathrm{~km}$ radius, $31.03 \%$ agree and $6.9 \%$ strongly agree that odour is a nuisance. For those in the $<0.9 \mathrm{~km}$ radius, $34.48 \%$ disagree and $27.59 \%$ strongly disagree of the ill-smelling landfill. Findings show that the farther the distance, the lower the respondent perception that 'odour is a nuisance'. Respondents in radius $>$
$7.0 \mathrm{~km}$ are the farthest from the odour source. The percentages generated on odour perception are as follows: $78.26 \%$ disagree that odour is a nuisance while $21.74 \%$ agree of the ill smell. Respondent perception decreases with distance. T-test is carried out to determine if respondent perception is influence by gender, type of house, and income. Table IV shows the factors and their significance to respondent perception on odour as a nuisance.

TABLE IV: RESPONDENT PERCEPTION ON ODOUR BASED ON GENDER, TYPE OF HOUSE, AND INCOME

\begin{tabular}{|c|c|c|c|c|c|c|}
\hline \multirow{2}{*}{$\begin{array}{c}\text { Distance from } \\
\text { Landfill and } \\
\text { Environmental } \\
\text { Issue }\end{array}$} & \multicolumn{2}{|c|}{$\begin{array}{c}\text { Gender } \\
\text { Perceptions }\end{array}$} & \multicolumn{2}{|c|}{$\begin{array}{c}\text { Type of House } \\
\text { Perceptions }\end{array}$} & \multicolumn{2}{|c|}{$\begin{array}{c}\text { Income } \\
\text { Perceptions }\end{array}$} \\
\hline & Sig. & $p$-value & Sig. & $p$-value & Sig. & $p$-value \\
\hline$<0.9 \mathrm{~km}$ & & 0.673 & & & & \\
\hline $1.0-1.9 \mathrm{~km}$ & $r$ & 0.013 & $r$ & 0.001 & & \\
\hline $3.0-3.9 \mathrm{~km}$ & & 0.842 & & & $\gamma$ & $<0.000$ \\
\hline $4.0-4.9 \mathrm{~km}$ & & 0.262 & & & & \\
\hline $5.0-5.9 \mathrm{~km}$ & & 0.441 & & & & \\
\hline $6.0-6.9 \mathrm{~km}$ & & 0.979 & $r$ & 0.018 & & \\
\hline$>7.0 \mathrm{~km}$ & & 0.808 & & & & 0.245 \\
\hline
\end{tabular}

In general, gender does not influence respondent perception on odour as a nuisance. Only respondents from distance $1.0-1.9 \mathrm{~km}$ are influenced by gender. In this radius-distance, 21 of the respondents are female and 18 are male. Respondents from this area live in houses constructed for plantation workers. Women generally stay at home and manage the family. Therefore, gender could have influenced the perception on odour because female respondents deal experience the ill-smelling odour everyday while managing their households, which are located near the landfill. There are only two distance tests for the type of household: those who live in villages and those in residential areas. In both radii-distances $(1.0-1.9$ and $6.0-6.9 \mathrm{~km})$, perception is influenced by the socioeconomic questionnaire item, type of house. At the distance of $1.9 \mathrm{~km}, 20$ respondents live in villages whereas 9 respondents live in residential areas. At distance $6.0-6.9 \mathrm{~km}, 76$ respondents live in villages whereas 182 live in residential areas. The imbalance in number of respondents for each type may have influenced respondent perception on odour. The different opinions among respondents (i.e., village vs. residential area dwellers) could have differed based on their socioeconomic status. People who live in villages have better sensitivity, and hence might cope well with odour, compared with respondents living in residential areas.

Table V shows the results from ANOVA corresponding to respondent perception on odour as nuisance based on age, race, education, occupation, and income. The test shows that only respondents living at the distance of $6.0-6.9 \mathrm{~km}$ are influenced by education; that is, respondents perceive that odour has turned into a nuisance in their area. The employees of the landfill are also influenced by education. The types of jobs the employees have in the landfill depend on their levels of education. Respondents with better education are employed in management and administration. They stay in the office or laboratory during working hours; under this setup, odour from the landfill is less pervasive. Employees with lower level or no education usually work at the site. 
TABLE V: RESPONDENT PERCEPTION ON OdOUR BASED ON Age, RACE, EDUCATION, OCCUPATION, AND INCOME

\begin{tabular}{lccccc}
\hline $\begin{array}{l}\text { Distance from } \\
\text { Landfill and } \\
\begin{array}{l}\text { Environmental } \\
\text { Issue }\end{array}\end{array}$ & $p$-value & $p$-value & $p$-value & $p$-value & $p$-value \\
\cline { 2 - 6 }$<\mathbf{0 . 9 9 9 k m}$ & 0.009 & & & & \\
\hline $\mathbf{1 . 0 - 1 . 9} \mathbf{~ k m}$ & & 0.257 & 0.265 & 0.176 & 0.498 \\
\hline $\mathbf{3 . 0 - 3 . 9} \mathbf{~ k m}$ & 0.695 & & 0.842 & 0.091 & \\
\hline $\mathbf{4 . 0 - 4 . 9} \mathbf{~ k m}$ & 0.751 & & 0.830 & 0.506 & 0.316 \\
\hline $\mathbf{5 . 0 - 5 . 9} \mathbf{~ k m}$ & 0.487 & 0.430 & 0.218 & 0.396 & 0.426 \\
\hline $\mathbf{6 . 0 - 6 . 9} \mathbf{~ k m}$ & 0.946 & 0.244 & 0.001 & 0.623 & 0.674 \\
\hline$>\mathbf{7} \mathbf{~ k m}$ & 0.393 & 0.116 & 0.277 & 0.187 & \\
\hline
\end{tabular}

Thus, they are exposed to odour as they work in the landfill. Evidently, the perception of respondents having different levels of education differs. Odour monitoring was carried out for 8 days. Monitoring is carried out at different times: 9 a.m., 10 a.m., 11 a.m., 12 noon, 1 p.m., 2 p.m., 3 p.m., 4 p.m., and 5 p.m. Fig. 2 shows the odour concentration at each radius-distance.

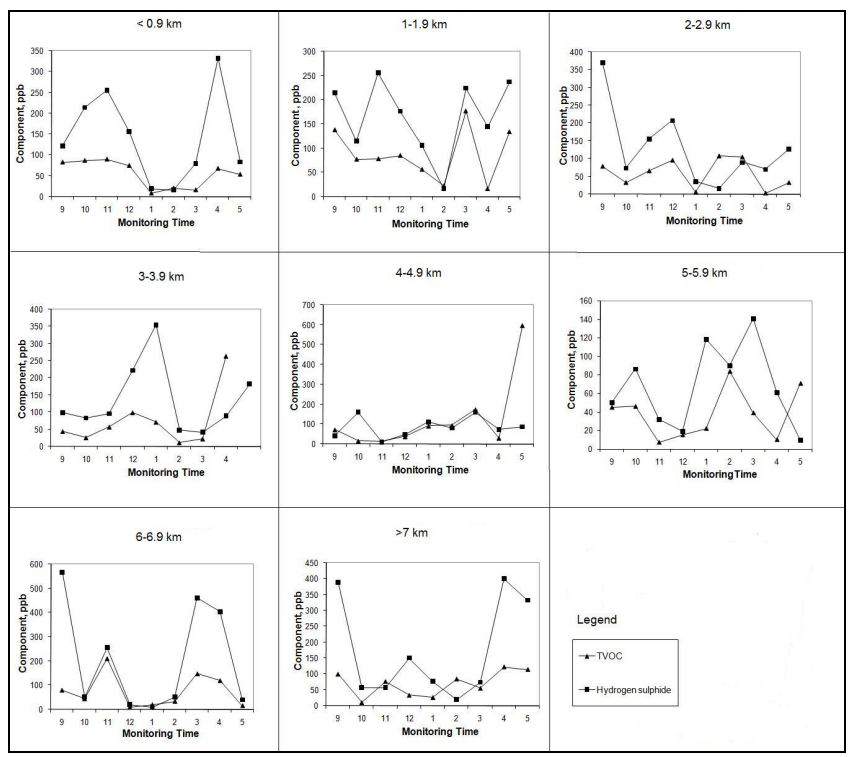

Fig. 2. Odour concentrations at each distance from the landfill

The concentration of odour emanating from the landfill to the communities is shown in Fig. 2. Results show that odour concentration is highest at 11 a.m. and 4 p.m. for the $<0.9 \mathrm{~km}$ radius-distance. Emission from landfill gives the highest odour concentration during this time because odour at this distance (i.e., $<0.9 \mathrm{~km}$ ) is measured at the landfill. At each distance, the concentrations of TVOC and $\mathrm{H}_{2} \mathrm{~S}$ notably increase and decrease in the same pattern. The highest odour concentration for $1-1.9 \mathrm{~km}$ is at 11 a.m., 3 p.m., and 5 p.m. The concentration at this distance has minimal difference with the $<0.9 \mathrm{~km}$ radius-distance because both are located fairly near the landfill. Odour concentration at the distance of $3.0-3.9,4.0-4.9,5.0-5.9,6.9$, and $>7 \mathrm{~km}$ experience odour at different times compared with those at the $<1.9 \mathrm{~km}$ radius-distance. Odour at distance $3.0-3.9$ and $>7 \mathrm{~km}$ is highest in the morning, whereas odour concentration is highest in the afternoon at $4.0-4.9,6.0-6.9$, and $>7 \mathrm{~km}$. Meanwhile, odour concentration is highest in the evening at the radius-distance of $5.0-5.9 \mathrm{~km}$. The different concentrations at each distance more likely resulted from odour emanating from the landfill; that is, it disperses to different locations and reduces concentration accordingly. However, odour from collection and transportation of wastes at different times of the day also influence respondent perception of odour. Such influence (i.e., on odour perception) manifest at different distances and at different times of the day.

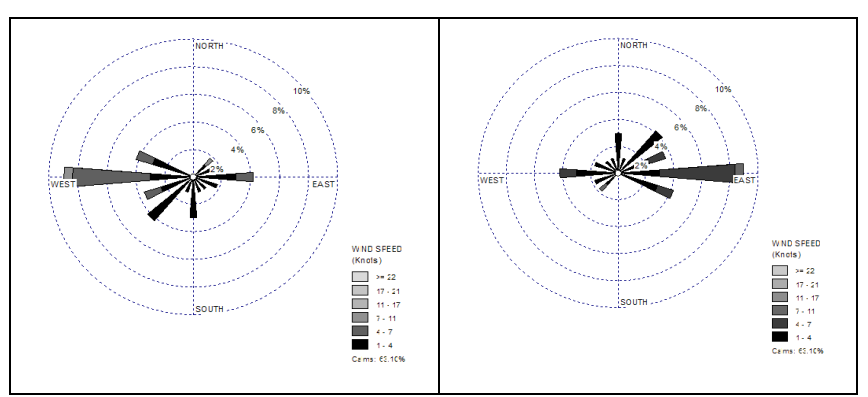

Fig. 3. Wind directions in the Pulau Burung Landfill Site for 28 days

Fig. 3 shows the wind profile moving from west to east based on the wind rose plot. Communities are largely located at the east side of PBLS. Gases move in a downwind pattern. As gases move, they expand in volume and incorporate diluted air around them. Odour concentration is reduced due to the movement of the gases. Gases also experience random movements caused by turbulence and then move away from the observed mean direction. These activities reduce the concentration of odour as it arrives at the receptor communities. Respondents living at the $<0.9 \mathrm{~km}$ radius-distance include employees of the landfill who are exposed to odour during working hours. There are no respondents in the $2.0-2.9 \mathrm{~km}$ range because this site is a plantation area (i.e., no residential/village population).

Respondents who live near the odour source agree that odour is a nuisance. Based on findings, $25.93 \%$ of the respondents who live within the $<0.9 \mathrm{~km}$ radius-distance strongly agree that 'odour is a nuisance', while $14.81 \%$ of the respondents completely agree of this odour perception, as high odour concentrations are recorded at this specific radius-distance. The level of agreement on odour as a nuisance decreases with distance. Only $3.33 \%$ of the respondents who live in the $4.0-4.9 \mathrm{~km}$ range agree that odour is a nuisance, which is in consensus with the perception of $1.16 \%$ of the respondents who live in the $6.0-$ $6.9 \mathrm{~km}$ range.

However, odour concentration does not decrease with distance. In fact, the concentration is high at each distance because it not only originates from the source, but also from waste collection and transportation activities. Therefore, respondents who live farther from the landfill also experience the ill effect of odour from these secondary sources. Tolerance to odour as nuisance differs across radius-distance, and this largely depends on the demographic characteristics of the respondents.

\section{CONCLUSION}

The study presented in this paper proves of the high number of respondents living near the source (landfill) who consider odour emanating from it as nuisance. Therefore, 
there is a need to contain intense odour emissions. The concentration of odour at a distance nearer to the origin greatly influences respondent perception. Nevertheless, the degree to which odour is perceived as a nuisance varies across distance. The survey has shown that there is better tolerance towards odour in locations farther from the source. The background and socioeconomic status of the respondents also influence their perceptions on odour. Respondents with higher tolerance can better cope with odour. Odour concentration may be high even at a distance far from the source, as concentration does not only originate from the landfill, but also from other emissions like those that accompany collection and transportation of wastes to the landfill.

\section{ACKNOWLEDGMENT}

Authors would like to thank the employees of Pulau Burung Landfill Site, as well as the residents of Nibong Tebal, Pulau Pinang, Malaysia for their cooperation and responses to this project.

\section{REFERENCES}

[1] S. Sironi, L. Capelli, P. Ce' ntola, R, Del Rosso, and M. Il Grande, "Odour emission factors for the assessment and prediction of Italian MSW landfills odour impact," Atmospheric Environmen, vol. 39, 2005, pp. 5387-5394.

[2] M. El Fadel, A.N. Findikakis, and J. O. Leckie, "Environmental impacts of solid waste landfilling," Journal of Environmental Management, vol. 50, 1997

[3] MHLG, Technical Section of the local Government Division. Kuala Lumpur, Malaysia, 2002

[4] T. L. Chong, Y. Matsufuju, and M. N. Hassan, "Implementation of Semi-aerobic Landfill System (Fukuoka Method) in Developing Countries: Malaysia Cost Analysis," Waste Management, vol. 25, pp. 702-711, 2005.

[5] P. T. Williams, Waste Treatment and Disposal, $2^{\text {nd }}$ Edition. Singapore: John Wiley \& Sons, Ltd. 2005

[6] M. Aatamila, P. K. Verkasalo, M. J. Korhonen, M. K. Viluksela, K. Pasanen, P. Tiittanen, and A. Nevalainen. "Odor annoyance near waste treatment centers: A population-based study in Finland," Air and Waste Management Association, vol. 60, pp. 412-418, 2010.

[7] U. Sarkar and S. E. Hobbs, "Odour from Municipal Solid Waste (MSW) landfills: a study on the analysis of perception," Environment International, vol. 27, vol. 8, 2002, 655-662.

[8] U. Sarkar and S. E. Hobbs, "Landfill Odour: Assessment of Emissions by Flux Footprint Method," Environmental Modelling \& Software, vol. 18, 2002, pp. 155-163.

[9] A. Sadowska-Rociek, M. Kurdziel, E. Szczepaniec-Cieciak, C. Riesenmey, H. Vaillant, M. Batton-Hubert, and K. Piejko, "Analysis of odorous compounds at municipal landfill sites," Waste Management and Research, vol. 27, 2009, pp. 966-975.

[10] D. Stretch, G. Laister, L. Strachan, M. Saner, M. Odour, "Trails From Landfill Sites," in Proc. the 8th International Waste Management \& Landfill Symposium, 2001, pp. 709-718.

[11] E-Komuniti Perda (October 2009). Peta Pulau Pinang. [Online] Available:

http://www.ekomunitiperda.icu.gov.my/eperda/petapulaupinang.htm

[12] R. E. Hester, R. M. Harisson, Environmental and Health Impact of Solid Waste Management Activities. United Kingdom: The Royal Society of Chemistry. 2002

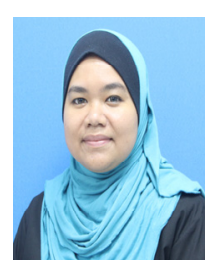

Tengku Nuraiti Tengku Izhara was born on 26 March 1982 in Kedah, Malaysia. She received her first degree in Bachelor of Engineering in Mineral Resources Engineering and MSc. in Environmental Engineering from Universiti Sains Malaysia, Malaysia. She also obtained her PhD in Environmental Engineering (Solid Waste Management) from Universiti Sains Malaysia on 2011. She is currently the Programme Chairman of Environmental Engineering Programme of Universiti Malaysia Perlis, Malaysia. She is a Member of Asia-Pacific Chemical, Biological \& Environmental Engineering Society, a member of Board of Engineers Malaysia and a member of Institute of Engineer Malaysia. The main areas of her interest include solid and hazardous waste management and methane gas production. She has presented and published technical paper in various international conferences.

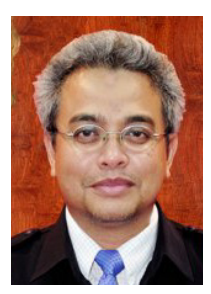

Nor Azam Ramli is a professor from Universiti Sains Malaysia, Malaysia. He received his first degree B.APP.Sc from Universiti Sains Malaysia. His M.Sc was in Environmental Impact assessment from Wales University. His Ph.D was from Wales University in Air Pollution. His expertise is in Air Pollution and Environmental Impact Assessment. He did a lot of research on Air Pollution in Malaysia, especially in Indoor Air Quality Monitoring and Air Quality Modelling and has published many high impact journals. He was always invited as a keynote speaker in local and international conference. He is also the advisor of Clean Air Research Group, Universiti Sains Malaysia, Malaysia.

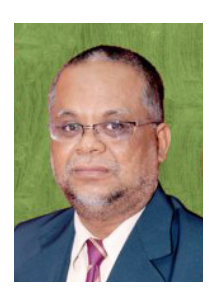

Ahmad Shukri Yahaya is a senior lecturer from Universiti Sains Malaysia, Malaysia. He received his first degree in Bachelor of Science in Mathematics from University of Nottingham and his M.Sc. in Industrial Mathematics from University of Aston, Birmingham. His expertise is in data analysis, simulation and operational research. He did a lot of research on Modelling and Simulation of various cases in Malaysia. He was always invited as a keynote speaker in local and international conference, as well as a consultant for local and international project. He is also the advisor of Clean Air Research Group, Universiti Sains Malaysia, Malaysia. He is the Chairman of Quality Planning of School of Civil Engineering, Universiti Sains Malaysia. 